\title{
Human galectin-3: Molecular switch of gene expression in dermal fibroblasts in vitro and of skin collagen organization in open wounds and tensile strength in incisions in vivo
}

\author{
PETER GÁL ${ }^{1-3}$, TOMÁŠ VASILENKO ${ }^{1,4}$, IVAN KOVÁČ ${ }^{1,5}$, MATÚŠ ČOMA ${ }^{1,6}$, JÁN JAKUBČO ${ }^{1}$, \\ MARTINA JAKUBČOVÁ ${ }^{1}$, VLASTA PERŽELOVÁ ${ }^{1}$, LUKÁŠ URBAN ${ }^{1,2}$, MICHAL KOLÁ $\check{R}^{7}$, \\ FRANTIŠEK SABOL ${ }^{8}$, JÁN LUCZY $^{8}$, MARTIN NOVOTNÝ $^{1,9}$, JAROSLAV MAJERNÍK $^{10}$, \\ HANS-JOACHIM GABIUS ${ }^{11}$ and KAREL SMETANA JR. ${ }^{12,13}$
}

\begin{abstract}
${ }^{1}$ Department of Biomedical Research, East-Slovak Institute of Cardiovascular Diseases; ${ }^{2}$ Laboratory of Cell Interactions, Center of Clinical and Preclinical Research, MediPark, Pavol Jozef Šafárik University, 04066 Košice, Slovak Republic;

${ }^{3}$ Prague Burn Centre, Third Faculty of Medicine, Charles University and University Hospital Kralovske Vinohrady, 10034 Prague, Czech Republic; ${ }^{4}$ Department of Surgery, Pavol Jozef Šafárik University and
\end{abstract}

First Private Hospital Košice-Šaca, 04015 Košice-Šaca; ${ }^{5}$ Second Department of Surgery, Pavol Jozef Šafárik University and Louis Pasteur University Hospital, 04190 Košice; ${ }^{6}$ Department of Pharmacology, Pavol Jozef Šafárik University, 04066 Košice, Slovak Republic; ${ }^{7}$ Laboratory of Genomics and Bioinformatics, Institute of Molecular Genetics of The Czech Academy of Sciences, 14220 Prague, Czech Republic; ${ }^{8}$ Department of Heart Surgery,

East-Slovak Institute of Cardiovascular Diseases, 04066 Košice; ${ }^{9}$ Department of Infectology and Travel Medicine, Louis Pasteur University Hospital and Pavol Jozef Šafárik University, 04190 Košice; ${ }^{10}$ Department of Medical Informatics, Faculty of Medicine, Pavol Jozef Šafárik University, 04066 Košice, Slovak Republic; ${ }^{11}$ Institute of Physiological Chemistry,

Faculty of Veterinary Medicine, Ludwig-Maximilian-University, D-80539 Munich, Germany; ${ }^{12}$ Institute of Anatomy,

First Faculty of Medicine, Charles University, 12800 Prague; ${ }^{13}$ BIOCEV, First Faculty of Medicine,

Charles University, 25250 Vestec, Czech Republic

Received July 3, 2020; Accepted October 2, 2020

DOI: $10.3892 / \mathrm{mmr} .2020 .11738$

\begin{abstract}
Understanding the molecular and cellular processes in skin wound healing can pave the way for devising innovative concepts by turning the identified natural effectors into therapeutic tools. Based on the concept of broad-scale engagement of members of the family of galactoside-binding lectins (galectins) in pathophysiological processes, such as cancer or tissue repair/regeneration, the present study investigated the potential of galectins-1 (Gal-1) and -3 (Gal-3) in wound healing. Human dermal fibroblasts, which are key cells involved in skin wound
\end{abstract}

Correspondence to: Dr Peter Gál, Laboratory of Cell Interactions, Center of Clinical and Preclinical Research, MediPark, Pavol Jozef Šafárik University, Trieda SNP 1, 04066 Košice, Slovak Republic E-mail:pgal@vusch.sk

Professor Karel Smetana Jr., Institute of Anatomy, First Faculty of Medicine, Charles University, U nemocnice 3, 12800 Prague, Czech Republic

E-mail: karel.smetana@lf1.cuni.cz

Key words: extracellular matrix, fibroblast, keratinocyte, lectin, regeneration healing, responded to galectin exposure (Gal-1 at 300 or Gal-3 at $600 \mathrm{ng} / \mathrm{ml}$ ) with selective changes in gene expression among a panel of 84 wound-healing-related genes, as well as remodeling of the extracellular matrix. In the case of Gal-3, positive expression of $\mathrm{Ki} 67$ and cell number increased when using a decellularized matrix produced by Gal-3-treated fibroblasts as substrate for culture of interfollicular keratinocytes. In vivo wounds were topically treated with $20 \mu \mathrm{g} / \mathrm{ml} \mathrm{Gal}-1$ or -3 , and collagen score was found to be elevated in excisional wound repair in rats treated with Gal-3. The tensile strength measured in incisions was significantly increased from $79.5 \pm 17.5 \mathrm{~g} / \mathrm{mm}^{2}$ in controls to $103.1 \pm 21.4 \mathrm{~g} / \mathrm{mm}^{2}$ after 21 days of healing. These data warrant further testing mixtures of galectins and other types of compounds, for example a combination of galectins and TGF- $\beta 1$.

\section{Introduction}

It is commonly known that acute and chronic wounds pose serious and unresolved treatment issues that increase morbidity and mortality, thus leading to increased healthcare costs. Bioinspired approaches derived from insights into mechanisms of healing can help to find solutions that improve skin repair. Initial steps in the direction of finding practical possibilities in this respect have been taken by exposing organ 
cultured human skin and wounded adult newts to plant agglutinins, such as phytohemagglutinin or concanavalin A $(1,2)$. Endogenous lectins in the skin, which are involved in healing pathways, would be superior candidates over exogenous reagents. Indeed, the skin is home to a variety of glycan receptors, including $\mathrm{C}$-type lectins and galactoside-binding lectins, or galectins.

Galectins are a family of $\beta$-sheet proteins synthesized on free ribosomes that exert various context-specific activities both intracellularly and following non-conventional secretion that do not involve the endo reticulum-Golgi route (3-12). First detected (as Mac-2 antigen) in the keratinocytes of murine skin (13) and also human skin (SL66) fibroblasts $(14,15)$, galectin-3 (Gal-3) has become a focus of research in this type of lectin in dermatology (16-23). In addition to its ability to bridge cell surface counterreceptors, thus reducing the rate of their dynamic endocytosis, Gal-3 is able to trigger changes in gene expression profiles by outside-in signaling, not only in human skin fibroblasts, but also in other types of cells (24-26). This evidence has prompted further exploration beyond Gal-3 to obtain a full view on galectin representation in skin. Since the presence of galectins has been described in human skin as a network (27), our previous studies examined their expression profiles in pig and rat skin during wound healing $(28,29)$. Based on the presence of several galectins in the skin and emerging insights into their regulation during wound healing, together with their known multifunctionality, it may be hypothesized that galectins may mechanistically be involved in this regenerative process.

In our previous study, this hypothesis was tested for six galectins in vitro, demonstrating their capacity to convert dermal fibroblasts into myofibroblasts and to remodel the extracellular matrix (ECM) (30). Moreover, these observations were dependent on galectin type and provided evidence that Gal-1 could reduce the area of an excisional wound in vivo in rats (30). In the present study, expression profiling of wound-healing-related genes was carried out in human dermal fibroblasts in vitro following exposure to Gal-1 and -3. Moreover, immunocytochemical analysis of keratinocytes cultured on an ECM substratum derived from the galectin-treated fibroblasts, histology of rat skin wounds, including collagen staining, and measurements of tensile strength of an incisional wound were also conducted in vivo. The present findings pointed to a potential beneficial role for human Gal-3 in the healing of skin incisions.

\section{Materials and methods}

Galectins. Human wild-type (WT) Gal-1 and -3 were obtained by recombinant production and purified by affinity chromatography on lactosylated Sepharose 4B prepared by ligand conjugation after activation of resin by divinyl sulfone. In the case His-tagged Gal-1 (E71Q) mutant (mutant that lost lectin activity by the site-directed mutagenesis), Ni-CAMTM HC (Sigma-Aldrich; Merck KGaA) was used. This was followed by the removal of any lipopolysaccharide contamination and desorption of bound (His-tagged) proteins by histidine $(31,32)$. Product analysis was performed using one- and two-dimensional gel electrophoresis, gel filtration and mass spectrometry, as well as carbohydrate-inhibitable hemagglutination and solid-phase assays in order to ascertain $\beta$-galactoside binding (or its loss) $(33,34)$.

Human dermal fibroblast (HDF) and human interfollicular keratinocyte (HIK) primary culture. HDFs and HIKs were isolated from the skin of healthy donors who underwent routine aesthetic surgery at the Department of Aesthetic Surgery, Third Faculty of Medicine, Charles University (Prague, Czech Republic). Written informed consent was obtained from all donors, in agreement with the Declaration of Helsinki and with approval from The Ethics Committee of University Hospital Kralovske Vinohrady and Third Faculty of Medicine, Charles University (approval no. 100/1947/2005). HDF cultures were expanded in Dulbecco's modified Eagle medium (DMEM) supplemented with 10\% FBS (both from Biochrom, Ltd.) and penicillin $(100 \mathrm{U} / \mathrm{ml}) /$ streptomycin (100 $\mu \mathrm{g} / \mathrm{ml}$; both from Biochrom, Ltd.), while HIKs were cultured in a mixture of DMEM and F12 (BioConcept AG) medium (3:1 vol:vol) containing 10\% FBS that was further enriched with insulin $(0.12 \mathrm{U} / \mathrm{ml}$; Novo Nordisk A/S $)$, cholera toxin (1 nM; Sigma-Aldrich; Merck KGaA), hydrocortisone $(0.4 \mu \mathrm{g} / \mathrm{ml}$; Sigma-Aldrich; Merck KGaA) and epidermal growth factor (10 ng/ml; Sigma-Aldrich; Merck KGaA) at $37^{\circ} \mathrm{C}$ with $5 \% \mathrm{CO}_{2}$, as described previously (35).

Isolation of RNA and reverse transcription $(R T)$. Following 48-h treatment with Gal-1 (300 ng/ml) and Gal-3 (600 ng/ml), total cellular RNA was isolated from HDFs using an RNeasy ${ }^{\circledR}$ Mini kit (Qiagen GmbH) according to the manufacturer's instructions. RNA quantification was performed with a NanoDrop ${ }^{\mathrm{TM}} 1000$ Spectrophotometer (NanoDrop Technologies; Thermo Fisher Scientific, Inc.), after which 250 ng total RNA was subjected to $1 \%$ agarose gel electrophoresis to confirm its integrity. The RNA samples were stored at $-80^{\circ} \mathrm{C}$. For analytical profiling, RNA was reverse transcribed using the RT ${ }^{2}$ First Strand kit (Qiagen $\mathrm{GmbH}$ ) following the manufacturer's instructions.

$R T$-quantitative $(R T-q) P C R$. $\mathrm{RT}^{2}$ Profiler PCR Array for Human Wound Healing (Qiagen $\mathrm{GmbH}$ ) was carried out using SYBR-Green as the reporter dye, according to the manufacturer's instructions. The RT array included reference genes, a control for excluding the presence of genomic DNA, three reverse-transcription controls and set of 84 wound-repair-related genes. Three positive RNA controls were also present. The sequences of forward and reverse primers were designed and supplied by Qiagen $\mathrm{GmbH}$. Two biological replicates were used for each sample group in two independent experimental batches and mRNA profiling was performed at two time points ( 24 and $48 \mathrm{~h}$ of culture). PCR was performed on an Applied Biosystems 7500 Fast Real-Time PCR System (Thermo Fisher Scientific, Inc.). The thermocycling conditions were set as follows: Initial denaturation step $\left(10 \mathrm{~min}, 95^{\circ} \mathrm{C}\right)$ was followed by 40 cycles each consisting of a denaturation step for $15 \mathrm{sec}$ at $95^{\circ} \mathrm{C}$ and annealing for $1 \mathrm{~min}$ at $60^{\circ} \mathrm{C}$. The obtained data were analyzed using the $2^{-\Delta \Delta \mathrm{Cq}}$ method (36), with the average expression of four housekeeping genes used as a reference ( $\beta$-actin, $\beta 2$-microglobulin, GAPDH and hypoxanthine phosphoribosyltransferase 1) to obtain relative expression values for each gene. The analysis was carried 
out using limma (version 3.42.2) (37). To detect differentially transcribed genes following treatment with Gal-1, -3 and TGF- $\beta 1$ (30 ng/ml; PeproTech EC Ltd.), groups were individually compared with the untreated control using a linear model and a moderated t-test. Genes with >2-fold up- or downregulation relative to the untreated control were considered statistically significant. Data and overlaps of differentially transcribed genes were visualized using gplots (version 3.0.3; https://github.com/talgalili/gplots) and Vennerable (version 3.1.0.9000; https:/github.com/js229/Vennerable) packages in $\mathrm{R}$ version 3.6.3 (https://www.r-project.org).

Culture of HIKs on ECM produced by galectin-treated $H D F s$. HDFs were seeded at a density of 2,000 cells $/ \mathrm{cm}^{2}$ and cultured for 10 days in the absence or presence of Gal-1 (WT or E71Q mutant) or Gal-3. Sterile solutions containing either no additive or Gal-1 (WT or E71Q mutant) at $300 \mathrm{ng} / \mathrm{ml}$ and Gal-3 at $600 \mathrm{ng} / \mathrm{ml}$, which were determined to be the most effective concentrations based on a previous experiment (30), were prepared in DMEM containing 10\% FBS and antibiotics. ECM scaffolds produced by the cell preparations cultured in parallel on the surface of glass microscope slide cover slips were tested as substrate for the HIKs. Cells were removed from cover slips by osmotic shock (exposure to sterile distilled water for $60 \mathrm{~min}$ ), then surfaces were covered with keratinocyte medium (mixture of DMEM and F12; 3:1) and cover slips were incubated for $24 \mathrm{~h}$. HIKs were seeded at a density of 10,000 cells $/ \mathrm{cm}^{2}$ and kept for 7 days at $5 \% \mathrm{CO}_{2}$ and $37^{\circ} \mathrm{C}$ prior to immunocytochemistry.

Immunocytochemistry of cultured cells. The tested specimens were fixed with $2 \%$ buffered paraformaldehyde $(\mathrm{pH} 7.2)$ for $5 \mathrm{~min}$ at room temperature and washed with phosphatebuffered saline (PBS; pH 7.2). Cells were permeabilized by exposure to Triton X-100 (Sigma-Aldrich; Merck KGaA), and sites for antigen-independent binding of antibodies were blocked by incubation with porcine serum albumin (diluted in PBS, 1:30; Dako; Agilent Technologies, Inc.) for $30 \mathrm{~min}$ at room temperature. Commercial antibodies were used at concentrations recommended by the suppliers (Table I). Incubations with primary and secondary antibodies were performed for 90 and $45 \mathrm{~min}$ at room temperature, respectively. Nuclear DNA was stained using DAPI for $1 \mathrm{~min}$ at room temperature. All specimens were mounted to Vectashield (Vector Laboratories, Inc.) and examined using an Eclipse 90i microscope equipped with filter blocks for the three types of dyes (Nikon Corporation), as well as a Cool-1300Q CCD camera (Vosskühler) and a computer-assisted image analysis system LUCIA 5.1 (Laboratory Imaging).

Cell counting. In vitro experiments were repeated twice to assess the expression of keratin-19 (K-19; marker of low-degree keratinocyte differentiation) and Ki67 (marker of proliferation). Staining (1 min at room temperature) of nuclear DNA with DAPI (Sigma-Aldrich; Merck KGaA) was performed so that the total numbers of HIKs per three visualization fields (magnification, x200) of each biological replicate could be counted, then positive expression of Ki67 and K-19 in cell populations was quantitated. The data are given as a percentage of the total number of counted cells. The aforementioned imaging system described for immunocytochemistry was also utilized for this assay.

Animal model. This study was approved by the Ethical Committee of the Faculty of Medicine of the Pavol Jozef Šafárik University (Košice, Slovak Republic) and by the State Veterinary Administration of the Slovak Republic. It was performed as described previously (30). A total of 96 male Sprague-Dawley rats (age, 1 years old; weight, 507 $\pm 48 \mathrm{~g}$ ) were included in the study. Animals were housed in plexiglass cages (22-24 ${ }^{\circ} \mathrm{C}, 50-70 \%$ relative humidity, $12 / 12 \mathrm{~h}$ light/dark cycles) with free access to food and water. Surgery was performed under general anesthesia induced by intramuscular administration of $40 \mathrm{mg} / \mathrm{kg}$ ketamine, $15 \mathrm{mg} / \mathrm{kg}$ xylazine and $5 \mathrm{mg} / \mathrm{kg}$ tramadol $(38,39)$. Under strict aseptic conditions, two $1-\mathrm{cm}$, round, full-thickness, excisional skin wounds and one $4-\mathrm{cm}$, full-thickness skin incision were inflicted to the back of each rat at the position depicted in Fig. 1. The incision was subsequently sutured using intradermal running suture. In each group, 6 rats were sacrificed on day 7 and 21 post-surgery, respectively. Allocation of rats to treatment groups is shown in Table II.

Wound treatment. In vivo experiments were performed in parallel under identical conditions, first on an exploratory level ( $\mathrm{n}=48$; data not shown) with galectin concentrations of $10 \mu \mathrm{g} / \mathrm{ml}$ (lyophilized protein containing $\mathrm{K} / \mathrm{Na}$-phosphate salts as buffer substances dissolved in physiological saline solution), then systematically $(n=48)$ with galectin concentrations of $20 \mu \mathrm{g} / \mathrm{ml}$ applied topically on the wound surface (using an eye dropper) during the first 3 post-operative days (three times a day).

Histology. Specimens of wounds were removed from rats sacrificed by cervical dislocation following ether anesthesia (using a vaporizer) at the two given time points and routinely processed for classical histological staining performed at room temperature (fixation in $4 \%$ buffered formaldehyde for $10 \mathrm{~min}$, dehydration using a series of solutions with increasing concentration of ethanol, paraffin embedding, sectioning). Deparaffinized sections ( $5 \mu \mathrm{m}$ thick) were stained with Van Gieson's solution (non-specific collagen staining) and also with hematoxylin for $10 \mathrm{~min}$ and eosin at $4 \mathrm{~min}$, according to a previous study (30). Sections were examined under an Olympus BX51 microscope equipped with an Olympus DP73 CCD camera (Olympus Corporation).

Immunohistochemistry. A second set of specimens of wounds was cryoprotected using Tissue-Tek (Sakura Finetek Europe B.V.) and frozen in liquid nitrogen. Tissue sections ( $\sim 10 \mu \mathrm{m}$ thickness) were first mounted on the surface of poly-l-lysine-treated glass slides (Sigma-Aldrich; Merck $\mathrm{KGaA})$, then fixed at room temperature using $2 \%(\mathrm{w} / \mathrm{v})$ paraformaldehyde in PBS for $10 \mathrm{~min}$. Non-specific binding of the secondary antibody was blocked at room temperature with normal swine serum (DakoCytomation; Agilent Technologies, Inc.) diluted with PBS (1:30) for $30 \mathrm{~min}$.

Solutions of commercially available primary and secondary antibodies are shown in Table I. Incubation with primary and 
Table I. Antibodies used for immunocytochemistry and lectin histochemistry.

A, Primary antibodies

\begin{tabular}{|c|c|c|c|c|}
\hline Name & Host & Supplier & Cat. no. & Dilution \\
\hline$\alpha$-smooth muscle actin & Mouse monoclonal & Dako (Agilent Technologies, Inc.) & M0851 & $1: 50$ \\
\hline Vimentin & Mouse monoclonal & Dako (Agilent Technologies, Inc.) & M0725 & $1: 200$ \\
\hline Tenascin & Mouse monoclonal & Sigma-Aldrich (Merck KGaA) & T3413 & $1: 200$ \\
\hline Fibronectin & Rabbit polyclonal & Dako (Agilent Technologies, Inc.) & $\mathrm{A} 0245$ & $1: 1,000$ \\
\hline Ki67 & Rabbit polyclonal & EMD Millipore & AB9260 & $1: 200$ \\
\hline
\end{tabular}

B, Secondary antibodies

\begin{tabular}{lllrr}
\hline Name & Host & Supplier & Cat. no. & Dilution \\
\hline Anti-mouse; TRITC & Goat & Sigma-Aldrich (Merck KGaA) & T5393 & $1: 30$ \\
Anti-rabbit; FITC & Swine & Dako (Agilent Technologies, Inc.) & F0205 & $1: 100$ \\
\hline
\end{tabular}

TRITC, tetramethyl rhodamine isothiocyanate; FITC, fluorescein isothiocyanate.

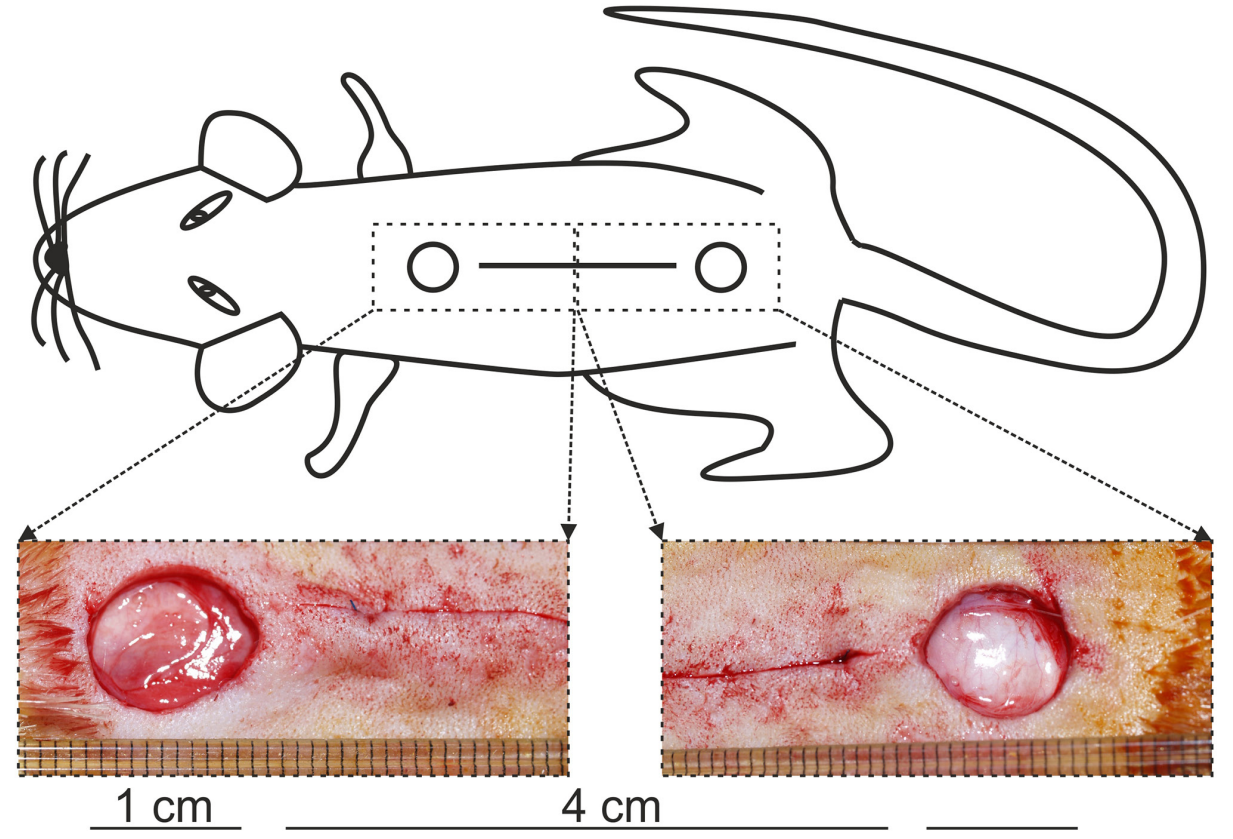

Figure 1. Schematic illustration and photograph showing the position and shape of wounds inflicted on the back of each rat. Two open wounds $1 \mathrm{~cm}$ in diameter each and one sutured incision $4 \mathrm{~cm}$ in length.

secondary antibodies was performed for 90 and 45 min (at room temperature), respectively. Nuclear DNA was stained using DAPI for $1 \mathrm{~min}$ at room temperature. Controls for specificity of the immunohistochemical detection were as follows: i) Replacement of the target-specific antibody by an irrelevant antibody (in the case of monoclonal antibodies of the same isotype); and ii) omission of the incubation step with the primary antibody to exclude antigen-independent signal generation. Specimens were mounted using Vectashield (Vector Laboratories, Inc.) and examined under an Eclipse 90i microscope (Nikon Corporation), as aforementioned.
Semi-quantitative scoring of histological sections. The status of re-epithelialization and extent of the presence of polymorphonuclear leukocytes (PMNL), fibroblasts, newly formed vessels and collagen were assessed according to a semi-quantitative scale system, as defined in Table III (40).

Wound tensile strength (TS). Measurement of force to rupture an incisional wound was facilitated by equipment assembled in our laboratory using commercial devices (41). Briefly, an adequately shaped horizontal arm was used to pull at one side of a specimen, while the opposite side was fixed to a sensor tip of a force meter 
Table II. Allocation of rats in treatment groups.

\begin{tabular}{|c|c|c|c|c|c|c|c|}
\hline \multirow[b]{2}{*}{ Time/group } & \multirow[b]{2}{*}{ Untreated control, $\mathrm{n}$} & \multicolumn{2}{|c|}{$\begin{array}{l}\text { Gal-1 } \\
\text { treatment group, } \mathrm{n}\end{array}$} & \multicolumn{2}{|c|}{$\begin{array}{c}\text { Gal-1(E71Q) } \\
\text { treatment group, } \mathrm{n}\end{array}$} & \multicolumn{2}{|c|}{$\begin{array}{l}\text { Gal-3 } \\
\text { treatment group }\end{array}$} \\
\hline & & $10 \mathrm{ng} / \mathrm{ml}$ & $20 \mathrm{ng} / \mathrm{ml}$ & $10 \mathrm{ng} / \mathrm{ml}$ & $20 \mathrm{ng} / \mathrm{ml}$ & $10 \mathrm{ng} / \mathrm{ml}$ & $20 \mathrm{ng} / \mathrm{ml}$ \\
\hline 7 days & 12 & 6 & 6 & 6 & 6 & 6 & 6 \\
\hline 21 days & 12 & 6 & 6 & 6 & 6 & 6 & 6 \\
\hline
\end{tabular}

Gal, galectin.

Table III. Scale used for the semi-quantitative evaluation of histological sections.

\begin{tabular}{llllll}
\hline Scale & \multicolumn{1}{c}{ Epithelialization } & \multicolumn{1}{c}{ PMNL } & Fibroblasts & Luminized vessels & Collagen \\
\hline 0 & Thickness of cut edges & Absent & Absent & Absent & Absent \\
1 & Migration of cells $(<50 \%)$ & Mild-ST & Mild-ST & Mild-SCT & Mild-GT \\
2 & Migration of cells $(\geq 50 \%)$ & Mild-DL/GT & Mild-GT & Mild-GT & Moderate-GT \\
3 & Bridging the excision & Moderate-DL/GT & Moderate-GT & Moderate-GT & Marked-GT \\
4 & Complete keratinization & Marked-DL/GT & Marked-GT & Marked-GT & Organized-GT \\
\hline
\end{tabular}

DL, demarcation line; GT, granulation tissue; PMNL, polymorphonuclear leucocyte; SCT, subcutaneous tissue; ST, surrounding tissue.

unit (Omega Engineering, Inc.). The moving arm was driven by a high-precision stepper motor MDI-17 (Intelligent Motion Systems Inc.) through a linear slider. The technique for determining the TS had been described in detail previously (42). Briefly, following euthanasia, two 1-cm-wide skin strips were removed from each incisional wound and placed lengthwise between the clamps of the TS testing device. Pulling was performed perpendicularly to the original direction of the incision. The maximal strength of rupture was measured for each specimen. TS $\left(\mathrm{g} / \mathrm{mm}^{2}\right)$ was calculated as TS=MRS/A, where MRS is the maximal rupture strength $(\mathrm{g})$ and $\mathrm{A}$ is the wound area $\left(\mathrm{mm}^{2}\right)$.

Statistical analysis. Continuous data are presented as the mean \pm SD. Categorical data are presented as the median. Data obtained from cell counting were compared using one-way ANOVA followed by the Tukey-Kramer post hoc test. Two-way ANOVA followed by Tukey's post hoc test was used to compare the effects of treatment modalities and time on wound TS. The Kruskal-Wallis test with multiple comparison (Dunn's test) was applied to compare non-parametric semi-quantitative data. The aforementioned statistical analyses were performed in SPSS v22 software (IBM Corp.). RT-qPCR data were analyzed using a moderated t-test in limma (version 3.42.2) (37) $\mathrm{R}$ version 3.6.3 (https://www.r-project.org) and Bioconductor version 3.1.0 software packages (http://www.bioconductor.org). $\mathrm{P}<0.05$ was considered to indicate a statistically significant difference.

\section{Results}

In vitro study. The influence of administration of the two galectins on biochemical and cellular features was tested in vitro in two experimental settings.
HDF gene expression profiling. In order to determine whether Gal-1 and -3 could affect HDF gene expression in vitro, the effective concentration required to induce conversion to myofibroblasts or ECM redesign (30), the Qiagen $\mathrm{RT}^{2}$ Profiler PCR Array for Human Wound Healing system was used to monitor expression levels of 84 selected genes relevant for wound healing. Technically, the sets of experiments recommended for stringent quality control completely satisfied the standards of this commercial system (data not shown). Indeed, Gal-1 led to significant changes of signal intensity relative to the control ( $\log _{2}$ fold change, 1.62-6.00; Fig. 2A). Genes with increased expression are presented in Table SI. Gal-3 treatment also caused deviations from the respective control from 1.14 to 6.28 $\log _{2}$ fold change upregulation relative to the control (Fig. 2A). There was considerable overlap between the lists of upregulated genes for Gal-1 and -3, including ANGPT1, IGF1, FGF10, F13A1 and ACTCl (Fig. 2B). In order to ascertain common responsiveness of cell populations to a known effector of fibroblast activation, TGF- $\beta 1$ was tested in parallel as a positive control (Table SI). Of note, a full overlap of profiles between TGF- $\beta 1$ and a Gal-1 was observed, whereas Gal-3 treatment resulted in uniquely regulated genes overlapping neither Gal-1 nor TGF- $\beta 1$ profiles, such as IL6, CDHI and F3 (Fig. 2B).

HIK immunocytochemistry. The low-level fibronectin staining at day 10 following HIK seeding demonstrated that the original three-dimensional structure of the ECM was completely replaced by a confluent layer of epithelial cells (Fig. 3A). The presence of fibronectin was restricted to small intracellular granules. K-19 was present in typically small cells, and a relative increase in the red signal was seen in the Gal-1-treated group, compared with the control, Gal-1(E71Q) mutant and Gal-3 conditions (Fig. 3A and B). Of note, the loss-of-glycan-binding 
A

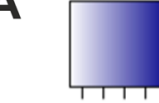

51525 Log2 (rel. expr.)

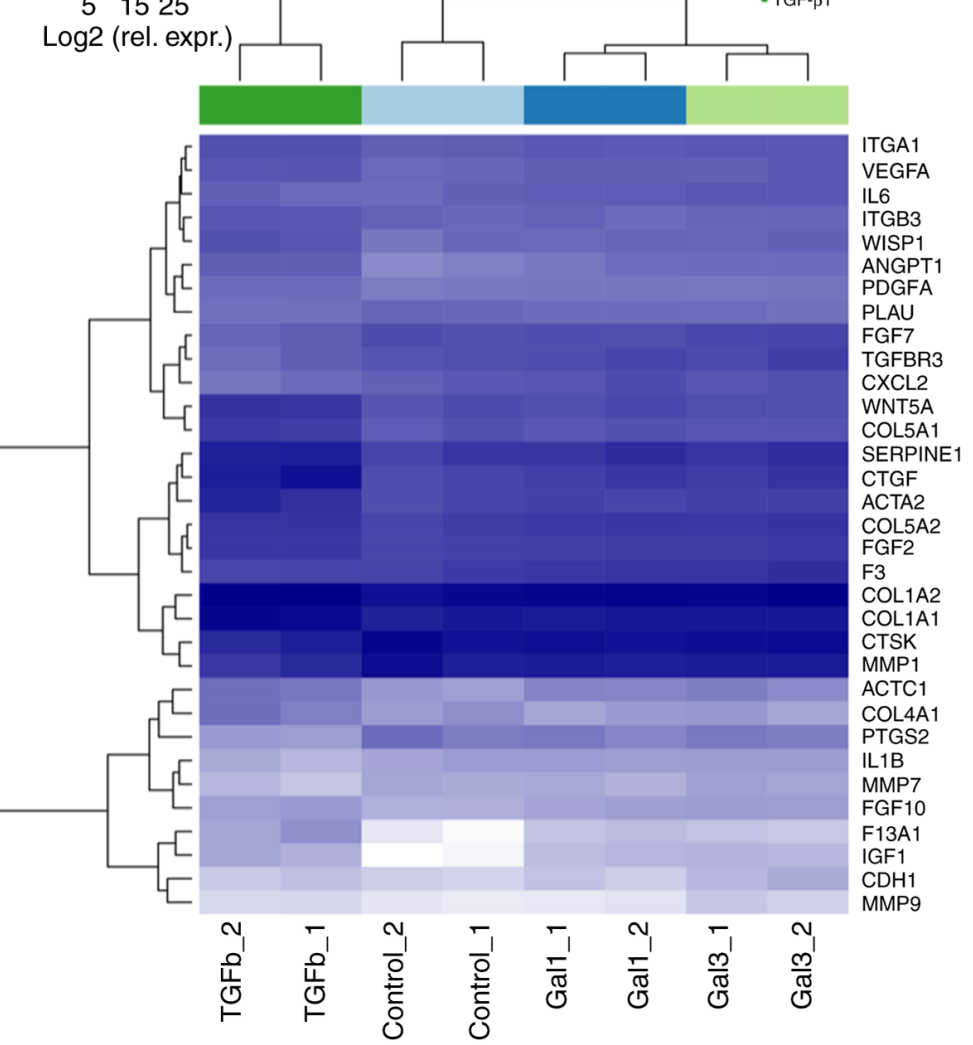

B

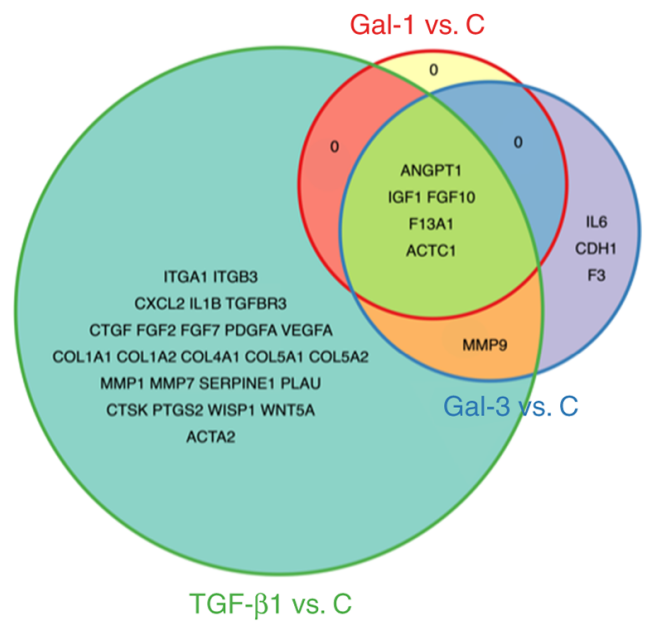

Figure 2.Expression profile of human dermal fibroblasts following treatment with Gal or TGF- $\beta 1$.(A) Heat map and (B) Venn diagram of genes separately/commonly regulated in human dermal fibroblasts following treatment with Gal-1, Gal-3 or TGF- $\beta 1$ compared to untreated control. Gal, galectin; C, control.

Gal-1 (Gal-1E71Q) single-site mutant did not trigger the pronounced effect of WT Gal-1 (Fig. 3A and B). As a measure of the growth fraction of cell populations, the Ki67 antigen status was assessed. Ki67-Positive HIKs were generally seen, most frequently for Gal-3 (Fig. 3B). Double staining suggested that K-19-positive cells did not present the Ki67 antigen (see insert in Fig. 3B), an observation made independent of the experimental condition.

Quantification of the observed parameters is presented in Fig. 3C-E. The increase in the positive expression of K-19 in Gal-1-treated cells was significant when compared with the control group, the Gal-1(E71Q) mutant- and Gal-3-treated cell populations (Fig. 3C). Positive expression of Ki67 was increased significantly in the Gal-1- and Gal-3-treated groups compared with the control and Gal-1(E71Q) mutant-treated cells, but not relative to each other (Fig. 3D). The total number of cells counted for each condition reached the most statistically significant level (among test groups) for Gal-3-exposed cells (Fig. 3E).

In vivo study. The effect of the two galectins on wound healing was tested on rats using two basic models of skin repair (open excision and sutured incision). During the post-surgical period, all animals remained healthy and did not show symptoms of infection. Initial experiments using concentrations of $10 \mu \mathrm{g} / \mathrm{ml}$ galectins showed no activity (data not shown). Thus, subsequent experiments were performed with $20 \mu \mathrm{g} / \mathrm{ml}$ concentrations (equal molar concentration due to similar molecular weights of Gal-1 homodimer and monomeric chimera-type Gal-3).

Histology of open excision wounds. The results of the extended histological analysis using immunohistochemistry and Van Gieson staining (top and middle panel) and of the semi-quantitative evaluation of distinct parameters of the wounds at the two time points (bottom panel) are shown in Fig. 4. At day 7, the newly formed granulation tissue (GT) was rich in fibronectin (Fig. 4A), populated by fibroblasts, and also notably vascularized. The inset in the photomicrograph of a section of a specimen of the Gal-1-treated group illustrates the already known capacity of this protein to generate SMA-positive myofibroblasts (Fig. 4A). When quantitated, the numbers of fibroblasts and luminized vessels were increased in both lectin-treated groups (Fig. 4C). An increase in collagen score was seen at this time point for Gal-3 (Fig. 4C).

At day 21, the level of fibronectin in the granulation tissue had leveled off, and no myofibroblasts were present in the granulation tissue of any group (data not shown). In contrast, the contents of collagen had further increased, as the Van Gieson staining in granulation tissue revealed (Fig. 4B and D). Inspection of such stained specimens under polarized light showed a marked effect of Gal-3 on collagen type-1 formation (Fig. 4B). Median values for scores of the measured characteristics reflect these microscopical observations, as they also indicate a tendency for an increase by presence of 
A
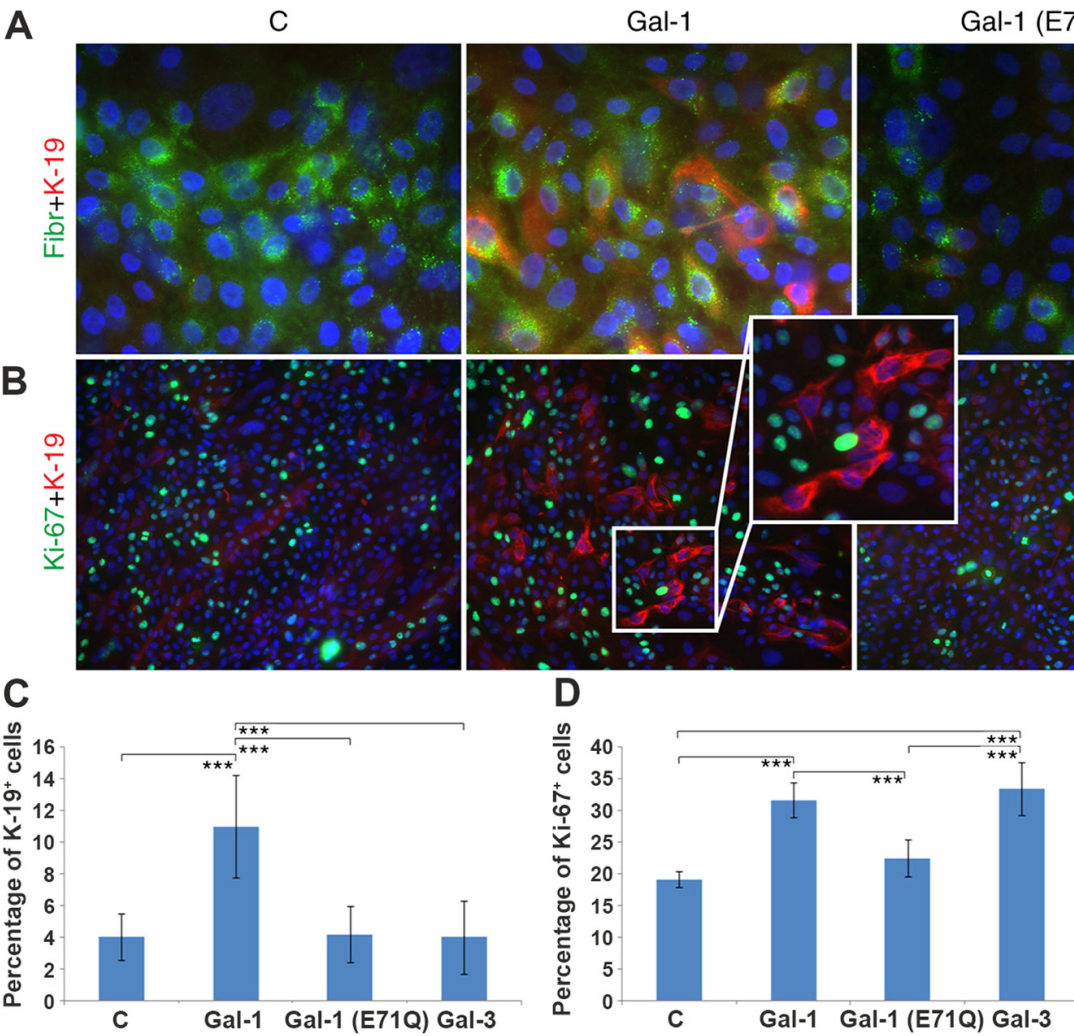

Gal-1 (E71Q)

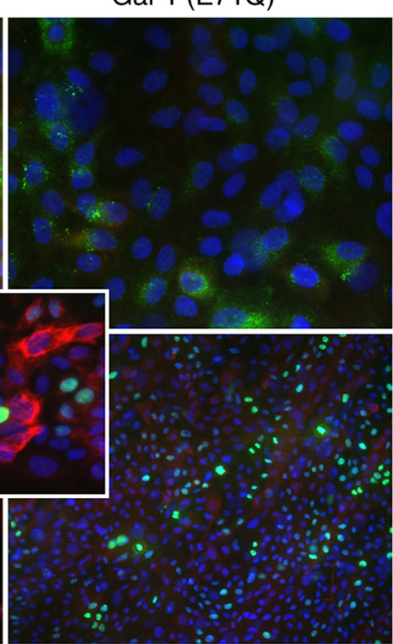

E

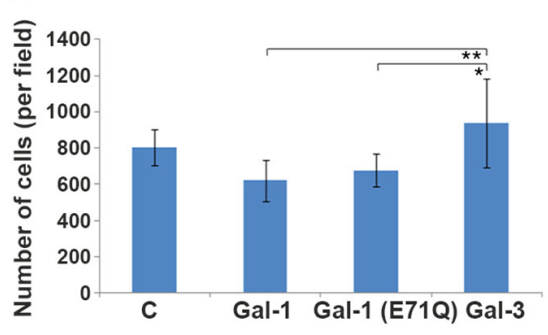

Figure 3. Characteristics of human interfollicular keratinocytes grown on an ECM produced by untreated or galectin-treated human dermal fibroblast cultures. Nuclei are counterstained with DAPI. (A) Cells were immunostained for the presence of Fibr (green signal) and K-19 (red signal). Magnification, x600. (B) Cells positive for Ki67 (green signal) and K-19 (red signal). Magnification, x200. Insert magnification, x400. (see insert, magnification 400x). Quantification of the studied parameters. (C) Frequency of K-19+ keratinocytes. (D) Frequency of Ki67 ${ }^{+}$cells. (E) Total number of cells in cultures using ECM from each group. ${ }^{*} \mathrm{P}<0.05,{ }^{* *} \mathrm{P}<0.01,{ }^{* * *} \mathrm{P}<0.001$. Gal, galectin; C, control; Fibr, fibronectin; ECM, extracellular matrix.

Gal-1 and -3 of the scores on re-epithelialization and number of fibroblasts (Fig. 4D).

TS of sutured incision wounds. Following the systematic determination of TS values of incisional wounds (Fig. 5), the results of the statistical analysis of these experimental series using the two-way ANOVA are summarized in Table IV. Data analysis using one-way ANOVA is presented in Fig. 5A and B.

As expected, a significant increase of wound TS was observed between day 7 and 21. The data from the Gal-3-treated group significantly differed from those of all other groups. At day 7, TS in the Gal-3 group reached $29.6 \pm 8.2 \mathrm{~g} / \mathrm{mm}^{2}$, compared with $14.3 \pm 9.6 \mathrm{~g} / \mathrm{mm}^{2}$ for the control, $20.2 \pm 7.6 \mathrm{~g} / \mathrm{mm}^{2}$ for Gal-1 and 17.4 $\pm 2.8 \mathrm{~g} / \mathrm{mm}^{2}$ for Gal-1(E71Q) (Fig. 5A).

At day 21 after surgery, the Gal-3 group continued to exhibit a significantly increased TS when compared with the untreated control (Gal-3, 103.1 $\pm 21.4 \mathrm{~g} / \mathrm{mm}^{2}$ vs. control, $\left.79.5 \pm 17.5 \mathrm{~g} / \mathrm{mm}^{2}\right)$, the Gal-1 group $\left(86.7 \pm 19.4 \mathrm{~g} / \mathrm{mm}^{2}\right)$ and the Gal-1(E71Q) mutant ( $\left.86.5 \pm 18.8 \mathrm{~g} / \mathrm{mm}^{2}\right)$ (Fig. 5B). Thus, TS is a parameter separating galectin activity in incisional skin wound healing.

\section{Discussion}

The data of the present study provided further evidence of the favorable effect of Gal-1 and -3 on excisional/open and incisional/sutured skin wound healing. Similar to TGF- $\beta 1$, the positive control, both galectins acted as molecular switches for the expression of genes related to the repair of skin wounds. Genes for IGF1, FGF10 and ANGPT1 were among the most upregulated genes, all of which have previously been implicated in healing processes (43-45). Multiplex cytokine assays of human skin fibroblasts after Gal-3 exposure have demonstrated the increased concentrations of interleukin-6, granulocyte-macrophage colony-stimulating factor, C-X-C motif chemokine ligand 8 and matrix metalloproteinase (MMP)-3, an overall pro-inflammatory/degradative signature $(24)$, in osteoarthritic chondrocytes $(25,46)$. On the other hand, the increase in the expression of MMP-9, cleaving the Ala62-Tyr63 bond in Gal-3's N-terminal stalk (47), can indicate a regulatory loop to put restrictions to prolonged Gal-3 activity for Gal-3-induced neutrophil activation by neutralizing contacts between lectin domains (48).

The ECM of the HDFs is then subject to a remodeling by Gal-3 that in turn induces proliferation of keratinocytes, extending our previous data on responses to Gal-1 presence (30). In detail, we observed significantly upregulated CDH1 (49) and MMP9 (50) transcripts in Gal-3 treated fibroblasts, which supports the role of lectins in the re-epithelialization of wounds. Reduced Gal-3 expression has been implicated in defective skin wound repair in patients with diabetes by two mechanisms: i) Inverse correlation between Gal-3 and advanced glycation end products; and ii) decreased Gal-3 in chronic human wounds leading to delayed re-epithelialization as seen also in Gal-3 knockout mice $(20,21)$. Of note, Gal-1 has been shown to accelerate 

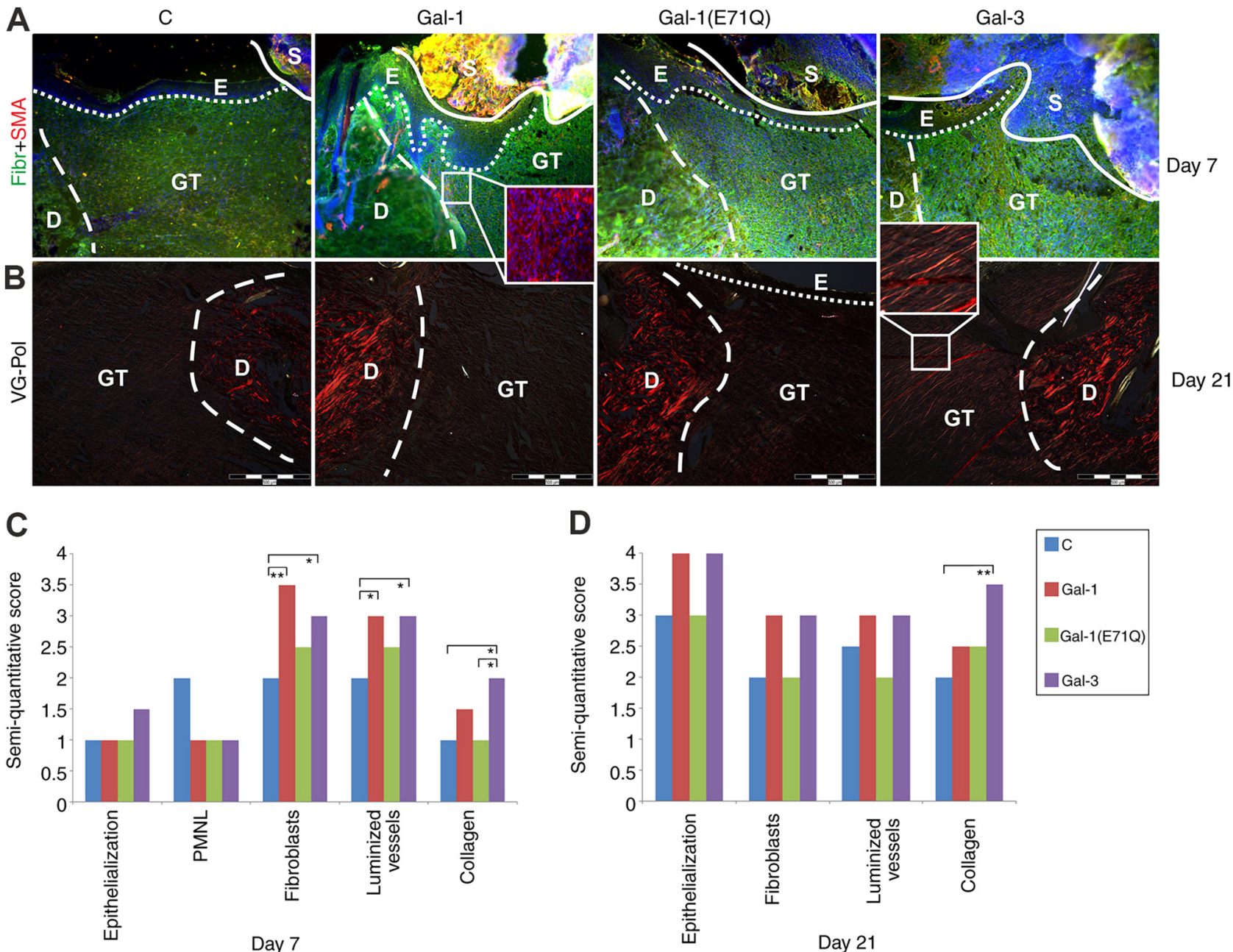

Figure 4. Characteristics of open wounds following treatment with tested galectins. Untreated group was used as C. Nuclei are counterstained with DAPI. (A) Sections of excisional wounds immunostained for Fibr (green signal) and SMA (red signal) seven days after surgery, presenting well-formed fibronectin-rich GT with SMA ${ }^{+}$vessels and re-epithelialization beneath scab can be seen in all groups, only Gal-1-treated wounds are characterized by increased number of SMA-positive myofibroblast-like cells. Magnification, x100. Insert magnification, x200. (B) VG-stained wounds monitored under polarized light 21 days after surgery, wounds treated with Gal-3 exhibited collagen organized into polarized light-reflecting fibers. Magnification, x100. Insert magnification, x200. Semi-quantitative analysis of histological parameters/changes. Data are presented as the median in two separate graphs for (C) day 7 and (D) day 21. PMNL was not evaluated at day 21. ${ }^{*} \mathrm{P}<0.05,{ }^{* *} \mathrm{P}<0.01$. Gal, galectin; C, control; SMA, $\alpha$-smooth muscle actin; Fibr, fibronectin; VG-Pol, Van Gieson-polarized light; D, dermis; E, epidermis; GT, granulation tissue; S, scab.
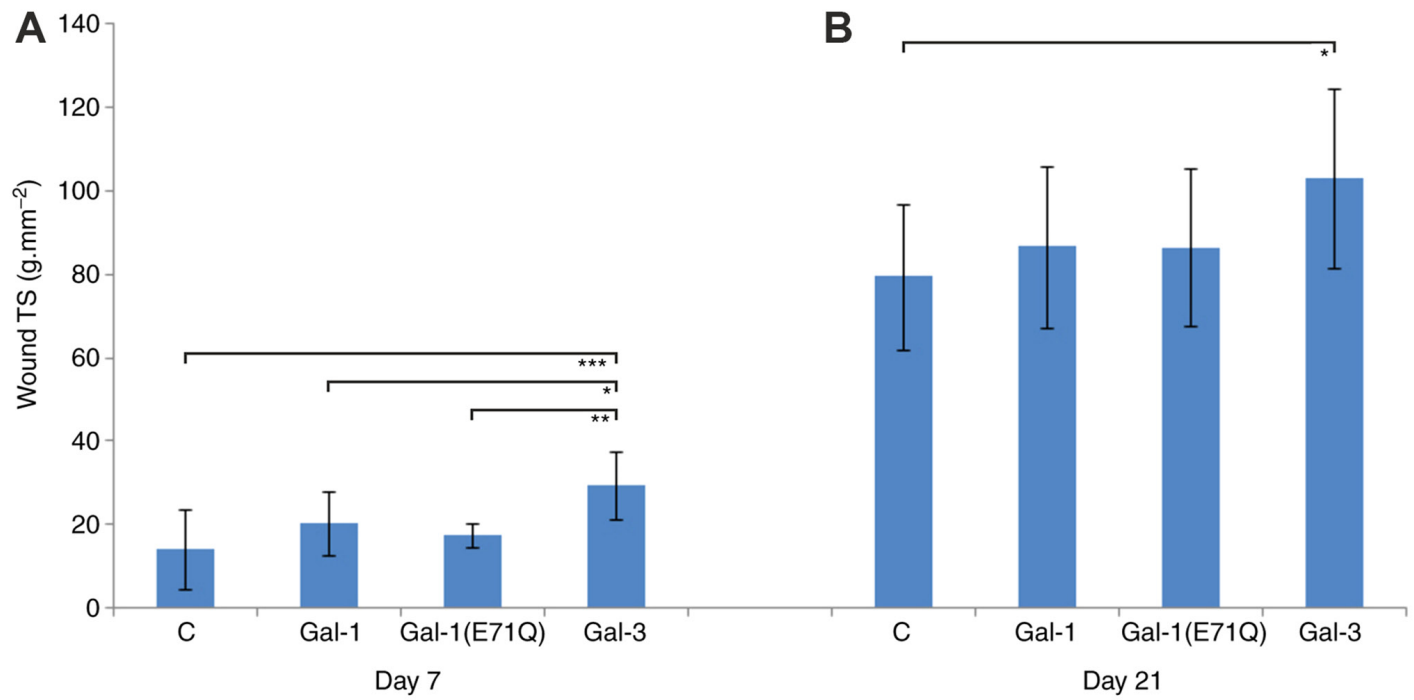

Figure 5. TS measurement of sutured wounds following treatment with Gal. TS of incisional wounds following treatment with Gal at (A) day 7 and (B) day 21 . Untreated group was used as C. One-way ANOVA followed by the Tukey-Kramer post hoc test. ${ }^{*} \mathrm{P}<0.05,{ }^{* * *} \mathrm{P}<0.01,{ }^{* * * *} \mathrm{P}<0.001$. TS, tensile strength; Gal, galectin; C, control. 
Table IV. Results from the statistical comparison of wound tensile strength using two-way ANOVA.

\section{A, Overall results}

\begin{tabular}{lcc}
\hline Group & P-value & $95 \%$ CI \\
\hline Time (7 days vs. 21 days) & $<0.001$ & N/A \\
Group (C vs. Gal-1 vs. & $<0.001$ & N/A \\
Gal-1(E71Q) vs. Gal-3) & & \\
Time vs. Group & 0.797 & N/A \\
\hline
\end{tabular}

$\mathrm{B}$, Time comparison

\begin{tabular}{lcc}
\hline Group & P-value & $95 \%$ CI \\
\hline 7 days vs. 21 days & 0.0001 & 62.3995 to 74.7000 \\
\hline
\end{tabular}

C, Treatment comparison

\begin{tabular}{lcc}
\hline Group & P-value & $95 \%$ CI \\
\hline C vs. Gal-1 & 0.8815 & -18.5813 to 5.5063 \\
C vs. Gal-1(E71Q) & 10.000 & -17.1219 to 6.9657 \\
C vs. Gal-3 & 0.0003 & -31.8079 to -7.1180 \\
Gal-1 vs. Gal-1(E71Q) & 10.000 & -9.8777 to 12.7964 \\
Gal-1 vs. Gal-3 & 0.0214 & -24.5819 to -1.2690 \\
Gal-3 vs. Gal-1(E71Q) & 0.0075 & 2.7284 to 26.0412 \\
\hline
\end{tabular}

C, control; Gal, galectin.

cellular migration and proliferation (51), and augment skin wound repair in normal and diabetic mice (deficient for this galectin) (52). In parallel, these processes may also contribute to the stability of wound closure, which prompted us to proceed with the animal study. In the present study, the pro-fibrotic effect of Gal-3 was demonstrated, resulting in wound tensile strength increase and improved collagen organization (characteristic reflective appearance of collagen fibers under the polarized light) of healing skin incisions and excisions, respectively. Molecular analysis further revealed significantly increased transcripts of IL6 and F3 genes in Gal-3-treated cells, more so than Gal-1-treated cells. In particular, IL- 6 and TGF- $\beta 1$ play important roles in liver fibrosis and/or structural changes in human tendon, a wound healing-like processes characterized by the accumulation and turnover of ECM (53-55). On the other hand, the $F 3$ gene product (tissue factor), exerts potent pro-angiogenic activity (56), which may also contribute to wound healing improvement in Gal-3-treated rats.

When envisioning to further pursue this route of experimental testing, two aspects should be noted. Firstly, galectins are expressed as a network beyond Gal-1 and -3 with possibility for context-dependent functional antagonism and cooperation (26,57-60). For example, our previous study reported an additive effect of TGF- $\beta 1(10 \mu \mathrm{g} / \mathrm{ml})$ with Gal-1 (200 or $300 \mathrm{ng} / \mathrm{ml}$ ) on inducing expression of SMA in HDF cultures (30). Further studies should investigate Gal-mixtures (also including other types of proteins such as TGF- $\beta 1$ ), as they likely occur in situ, to attain the optimal efficacy, and the present study provides a solid foundation for this. Secondly, galectin function arises from their modular structure. Therefore, their protein architecture has become the subject of redesign using engineering, for example by creating homo-oligomers from natural dimers (61-64), in order to optimize a favorable activity. Of note, whether and how a Gal-1-like (homodimeric) Gal-3 or a Gal-3-like (monomeric, in solution) Gal-1 will influence in vitro and in vivo aspects of wound healing remains to be determined.

In summary, the present findings provided further evidence that galectins should be listed within the group of efficient wound healing modulators at several key steps of skin repair, including ECM formation/reorganization and re-epithelialization $(65,66)$. This conclusion is incentive for further work. From a clinical perspective, the present data makes a strong case for directing further efforts to treat incisional and excisional wounds differently. In fact, Gal-1 seems to play a role in wound contraction, whereas Gal-3 seems to be a skin scar inductor. However, understanding the activity profile of each galectin in vitro and in acute and chronic wound repair, along with the potential of administration of mixtures, including custom-made variants in experimental in vitro and in vivo testing $(67,68)$, will be important when investigating the potential applications of these endogenous effectors in the treatment of skin lesions.

\section{Acknowledgements}

The authors would like to thank Dr B Dvořánková, Ms I Burdová, Ms H Stýblová (all, Institute of Anatomy, First Faculty of Medicine, Charles University) and Ms M Majnušová (Department of Forensic Medicine, P.J. Šafárik University in Košice) for their expert technical assistance, and Dr B Friday, Dr A Leddoz and Dr AWL Nose for inspiring discussions.

\section{Funding}

This study was supported by Slovak Research and Development Agency (grant no. APVV-14-0731), Slovak Grant Agency (grant nos. VEGA-1/0319/20 and VEGA-1/0561/18), Charles University (grant nos. PROGRES Q28 and Q37), Operational Programme Research, Development and Education (Center for Tumor Ecology, Research of the Cancer Microenvironment Supporting Cancer Growth and Spread; grant no. CZ.02.1.01/0.0/0.0/16_019/0000785), Research and Development for Innovations Operational Program (grant no. CZ.1.05/2.1.00/19.0400; co-financed by the European Union Regional Development Fund and State Budget of Czech Republic), Medical University Science Park in Košice supported by Operational Programme Research \& Innovation (grant nos. ITMS2014 and 313011D103), and COST (European Cooperation in Science and Technology) Action (InnoGly-INNOvation with Glycans, grant no. CA18103).

\section{Availability of data and materials}

The datasets used and/or analyzed during the current study are available from the corresponding author on reasonable request. 


\section{Authors' contributions}

PG, HJG, FS, JL and KS acquired funding and made substantial contributions to conception and design of the study. PG, TV, IK, MČ, JJ, MJ, VP, LU, MK, MN and JM performed the experiments. FS and JL supervised the animal study. HJG and KS validated the obtained data. PG and HJG wrote the original draft. All authors read and approved the final manuscript.

\section{Ethics approval and consent to participate}

The use of clinical samples was approved by The Ethics Committee of University Hospital Kralovske Vinohrady and Third Faculty of Medicine, Charles University (approval no. 100/1947/2005). Human cells were isolated and cultured with informed consent from the donors. The animal study was approved by the Ethics Committee of the Faculty of Medicine of the P. J. Šafárik University and by the State Veterinary Administration of the Slovak Republic (approval nos. Ro-580/10-221a and Ro-2617/15-221a).

\section{Patient consent for publication}

Not applicable.

\section{Competing interests}

The authors declare that they have no competing interests.

\section{References}

1. Gaylarde PM and Sarkany I: Cell migration and DNA synthesis in organ culture of human skin. Br J Dermatol 92: 375-380, 1975

2. Donaldson DJ and Mason JM: Inhibition of epidermal cell migration by concanavalin A in skin wounds of the adult newt. J Exp Zool 200: 55-64, 1977.

3. Harrison FL and Chesterton CJ: Factors mediating cell-cell recognition and adhesion. Galaptins, a recently discovered class of bridging molecules. FEBS Lett 122: 157-165, 1980.

4. Barondes SH: Galectins: A personal overview. Trends Glycosci Glycotechnol 9: 1-7, 1997.

5. Hughes RC: Secretion of the galectin family of mammalian carbohydrate-binding proteins. Biochim Biophys Acta 1473: $172-185,1999$.

6. Liu FT, Patterson RJ and Wang JL: Intracellular functions of galectins. Biochim Biophys Acta 1572: 263-273, 2002.

7. Thiemann S and Baum LG: Galectins and immune responses-just how do they do those things they do? Annu Rev Immunol 34 243-264, 2016

8. Kaltner H, Toegel S, Caballero GG, Manning JC, Ledeen RW and Gabius HJ: Galectins: Their network and roles in immunity/ tumor growth control. Histochem Cell Biol 147: 239-256, 2017.

9. Sato S: Cytosolic galectins and their release and roles as carbohydrate-binding proteins in host-pathogen interaction. Trends Glycosci Glycotechnol 30: SE199-SE209, 2018.

10. de Jong CGHM, Gabius HJ and Baron W: The emerging role of galectins in (re)myelination and its potential for developing new approaches to treat multiple sclerosis. Cell Mol Life Sci 77: $1289-1317,2020$.

11. García Caballero G, Kaltner H, Kutzner TJ, Ludwig AK, Manning JC, Schmidt S, Sinowatz F and Gabius HJ: How galectins have become multifunctional proteins. Histol Histopathol 35 509-539, 2020

12. Kutzner TJ, Higuero AM, Süssmair M, Kopitz J, Hingar M, Díez-Revuelta N, Caballero GG, Kaltner H, Lindner I, Abad-Rodríguez J, et al: How presence of a signal peptide affects human galectins- 1 and -4 : Clues to explain common absence of a leader sequence among adhesion/growth-regulatory galectins. Biochim Biophys Acta Gen Subj 1864: 129449, 2020.
13. Flotte TJ, Springer TA and Thorbecke GJ: Dendritic cell and macrophage staining by monoclonal antibodies in tissue sections and epidermal sheets. Am J Pathol 111: 112-124, 1983.

14. Roff CF, Rosevear PR, Wang JL and Barker R: Identification of carbohydrate-binding proteins from mouse and human fibroblasts. Biochem J 211: 625-629, 1983.

15. Cowles EA, Moutsatsos IK, Wang JL and Anderson RL: Expression of carbohydrate binding protein 35 in human fibroblasts: Comparisons between cells with different proliferative capacities. Exp Gerontol 24: 577-585, 1989.

16. Wollenberg A, de la Salle H, Hanau D, Liu FT and Bieber T: Human keratinocytes release the endogenous beta-galactoside-binding soluble lectin immunoglobulin E (IgE-binding protein) which binds to Langerhans cells where it modulates their binding capacity for IgE glycoforms. J Exp Med 178: 777-785, 1993.

17. Konstantinov KN, Shames B, Izuno G and Liu FT: Expression of epsilon BP, a beta-galactoside-binding soluble lectin, in normal and neoplastic epidermis. Exp Dermatol 3: 9-16, 1994.

18. Holiková Z, Smetana K Jr, Bartunková J, Dvoránková B, Kaltner $\mathrm{H}$ and Gabius HJ: Human epidermal langerhans cells are selectively recognized by galectin-3 but not by galectin-1. Folia Biol (Praha) 46: 195-198, 2000.

19. Larsen L, Chen HY, Saegusa J and Liu FT: Galectin-3 and the skin. J Dermatol Sci 64: 85-91, 2011

20. Pepe D, Elliott CG, Forbes TL and Hamilton DW: Detection of galectin-3 and localization of advanced glycation end products (AGE) in human chronic skin wounds. Histol Histopathol 29: 251-258, 2014.

21. Walker JT, Elliott CG, Forbes TL and Hamilton DW: Genetic deletion of galectin-3 does not impair full-thickness excisional skin healing. J Invest Dermatol 136: 1042-1050, 2016.

22. McLeod K, Walker JT and Hamilton DW: Galectin-3 regulation of wound healing and fibrotic processes: Insights for chronic skin wound therapeutics. J Cell Commun Signal 12: 281-287, 2018.

23. Wu NL and Liu FT: The expression and function of galectins in skin physiology and pathology. Exp Dermatol 27: 217-226, 2018.

24. Filer A, Bik M, Parsonage GN, Fitton J, Trebilcock E, Howlett K, Cook M, Raza K, Simmons DL, Thomas AM, et al: Galectin-3 induces a distinctive pattern of cytokine and chemokine production in rheumatoid synovial fibroblasts via selective signaling pathways. Arthritis Rheum 60: 1604-1614, 2009.

25. Weinmann D, Schlangen K, André S, Schmidt S, Walzer SM, Kubista B, Windhager R, Toegel S and Gabius HJ: Galectin-3 induces a pro-degradative/inflammatory gene signature in human chondrocytes, teaming up with galectin-1 in osteoarthritis pathogenesis. Sci Rep 6: 39112, 2016.

26. Weinmann D, Kenn M, Schmidt S, Schmidt K, Walzer SM, Kubista B, Windhager R, Schreiner W, Toegel S and Gabius HJ: Galectin-8 induces functional disease markers in human osteoarthritis and cooperates with galectins-1 and -3. Cell Mol Life Sci 75: 4187-4205, 2018.

27. Cada Z, Smetana K Jr, Lacina L, Plzáková Z, Stork J, Kaltner H, Russwurm R, Lensch M, André S and Gabius HJ: Immunohistochemical fingerprinting of the network of seven adhesion/growth-regulatory lectins in human skin and detection of distinct tumor-associated alterations. Folia Biol (Praha) 55: 145-152, 2009.

28. Klíma J, Lacina L, Dvorankova B, Herrmann D, Carnwath JW, Niemann H, Kaltner H, André S, Motlík J, Gabius HJ and Smetana K Jr: Differential regulation of galectin expression/reactivity during wound healing in porcine skin and in cultures of epidermal cells with functional impact on migration. Physiol Res 58: 873-884, 2009.

29. Gál P, Vasilenko T, Kostelniková M, Jakubco J, Kovác I, Sabol F, André S, Kaltner H, Gabius HJ and Smetana K Jr: Open wound healing in vivo: Monitoring binding and presence of adhesion/growth-regulatory galectins in rat skin during the course of complete re-epithelialization. Acta Histochem Cytochem 44: 191-199, 2011.

30. Dvoránková B, Szabo P, Lacina L, Gal P, Uhrova J, Zima T, Kaltner H, André S, Gabius HJ, Sykova E and Smetana K Jr: Human galectins induce conversion of dermal fibroblasts into myofibroblasts and production of extracellular matrix: Potential application in tissue engineering and wound repair. Cells Tissues Organs 194: 469-480, 2011

31. Gabius HJ: Influence of type of linkage and spacer on the interaction of beta-galactoside-binding proteins with immobilized affinity ligands. Anal Biochem 189: 91-94, 1990. 
32. Sarter K, André S, Kaltner H, Lensch M, Schulze C, Urbonaviciute V, Schett G, Herrmann M and Gabius HJ: Detection and chromatographic removal of lipopolysaccharide in preparations of multifunctional galectins. Biochem Biophys Res Commun 379: 155-159, 2009.

33. Kopitz J, Vértesy S, André S, Fiedler S, Schnölzer M and Gabius HJ: Human chimera-type galectin-3: Defining the critical tail length for high-affinity glycoprotein/cell surface binding and functional competition with galectin-1 in neuroblastoma cell growth regulation. Biochimie 104: 90-99, 2014.

34. García Caballero G, Kaltner H, Michalak M, Shilova N, Yegres M, André S, Ludwig AK, Manning JC, Schmidt S, Schnölzer M, et al: Chicken GRIFIN: A homodimeric member of the galectin network with canonical properties and a unique expression profile. Biochimie 128-129: 34-47, 2016.

35. Rheinwald JG and Green H: Serial cultivation of strains of human epidermal keratinocytes: The formation of keratinizing colonies from single cells. Cell 6: 331-343, 1975.

36. Livak KJ and Schmittgen TD: Analysis of relative gene expression data using real-time quantitative PCR and the 2(-Delta Delta C(T)) method. Methods 25: 402-408, 2001

37. Ritchie ME, Phipson B, Wu D, Hu Y, Law CW, Shi W and Smyth GK Limma powers differential expression analyses for RNA-sequencing and microarray studies. Nucleic Acids Res 43: e47, 2015

38. Perzelova V, Sabol F, Vasilenko T, Novotný M, Kováč I, Slezák M, Durkáč J, Hollý M, Pilátová M, Szabo P, et al: Pharmacological activation of estrogen receptors- $\alpha$ and $-\beta$ differentially modulates keratinocyte differentiation with functional impact on wound healing. Int J Mol Med 37: 21-28, 2016.

39. Kovac I, Melegova N, Coma M, Takáč P, Kováčová K, Hollý M, Durkáč J, Urban L, Gurbálová M, Śvajdlenka E, et al: Aesculus hippocastanum L . extract does not induce fibroblast to myofibroblast conversion but increases extracellular matrix production in vitro leading to increased wound tensile strength in rats. Molecules 25: 1917, 2020.

40. Kovac I, Durkac J, Holly M, Jakubčová K, Peržel’ová V, Mučaji P, Švajdlenka E, Sabol F, Legáth J, Belák J, et al: Plantago lanceolata L. water extract induces transition of fibroblasts into myofibroblasts and increases tensile strength of healing skin wounds. J Pharm Pharmacol 67: 117-125, 2015.

41. Sabol F, Vasilenko T, Novotny M, Tomori Z, Bobrov N, Zivčák J, Hudák R and Gál P: Intradermal running suture versus $3 \mathrm{M}^{\mathrm{TM}}$ Vetbond $^{\mathrm{TM}}$ tissue adhesive for wound closure in rodents: A biomechanical and histological study. Eur Surg Res 45: 321-326, 2010.

42. Gál P, Toporcer T, Vidinsky B, Hudak R, Zivcak J and Sabo J: Simple interrupted percutaneous suture versus intradermal running suture for wound tensile strength measurement in rats: A technical note. Eur Surg Res 43: 61-65, 2009 .

43. Koshizuka S, Kanazawa K, Kobayashi N, Takazawa I, Waki Y, Shibusawa $\mathrm{H}$ and Shumiya $\mathrm{S}$ : The beneficial effects of recombinant human insulin-like growth factor-I (IGF-I) on wound healing in severely wounded senescent mice. Surg Today 27: 946-952, 1997.

44. Cho CH, Sung HK, Kim KT, Cheon HG, Oh GT, Hong HJ, Yoo OJ and Koh GY: COMP-angiopoietin-1 promotes wound healing through enhanced angiogenesis, lymphangiogenesis, and blood flow in a diabetic mouse model. Proc Natl Acad Sci USA 103: 4946-4951, 2006

45. Quirinia A and Viidik A: The effect of recombinant basic fibroblast growth factor (bFGF) in fibrin adhesive vehicle on the healing of ischaemic and normal incisional skin wounds. Scand J Plast Reconstr Surg Hand Surg 32: 9-18, 1998

46. Toegel S, Weinmann D, André S, Walzer SM, Bilban M, Schmidt S Chiari C, Windhager R, Krall C, Bennani-Baiti IM and Gabius HJ: Galectin-1 couples glycobiology to inflammation in osteoarthritis through the activation of an NF- $\mathrm{BB}$-regulated gene network. J Immunol 196: 1910-1921, 2016.

47. Ochieng J, Fridman R, Nangia-Makker P, Kleiner DE, Liotta LA, Stetler-Stevenson WG and Raz A: Galectin-3 is a novel substrate for human matrix metalloproteinases-2 and -9 . Biochemistry 33 : 14109-14114, 1994.

48. Sundqvist M, Welin A, Elmwall J, Osla V, Nilsson UJ, Leffler H, Bylund $J$ and Karlsson A: Galectin-3 type-C self-association on neutrophil surfaces: The carbohydrate recognition domain regulates cell function. J Leukoc Biol 103: 341-353, 2018.

49. Advedissian T, Proux-Gillardeaux V, Nkosi R, Peyret G, Nguyen T, Poirier F, Viguier M and Deshayes F: E-cadherin dynamics is regulated by galectin-7 at epithelial cell surface. Sci Rep 7: 17086, 2017.

50. Kyriakides TR, Wulsin D, Skokos EA, Fleckman P, Pirrone A, Shipley JM, Senior RM and Bornstein P: Mice that lack matrix metalloproteinase-9 display delayed wound healing associated with delayed reepithelization and disordered collagen fibrillogenesis. Matrix Biol 28: 65-73, 2009.
51. Kim MH, Wu WH, Choi JH, Kim J, Jun JH, Ko Y and Lee JH: Galectin-1 from conditioned medium of three-dimensional culture of adipose-derived stem cells accelerates migration and proliferation of human keratinocytes and fibroblasts. Wound Repair Regen 26 (Suppl 1): S9-S18, 2018.

52. Liu W, Hsu DK, Chen HY, Yang RY, Carraway KL III, Isseroff RR and Liu FT: Galectin-3 regulates intracellular trafficking of EGFR through Alix and promotes keratinocyte migration. J Invest Dermatol 132: 2828-2837, 2012.

53. Kershenobich Stalnikowitz D and Weissbrod AB: Liver fibrosis and inflammation. A review. Ann Hepatol 2: 159-163, 2003.

54. Kjaer M, Langberg H, Heinemeier K, Bayer ML, Hansen M, Holm L, Doessing S, Kongsgaard M, Krogsgaard MR and Magnusson SP: From mechanical loading to collagen synthesis, structural changes and function in human tendon. Scand J Med Sci Sports 19: 500-510, 2009.

55. Kjaer M, Magnusson P, Krogsgaard M, Boysen Møller J, Olesen J, Heinemeier K, Hansen M, Haraldsson B, Koskinen S, Esmarck B and Langberg $\mathrm{H}$ : Extracellular matrix adaptation of tendon and skeletal muscle to exercise. J Anat 208: 445-450, 2006.

56. Pena E, de la Torre R, Arderiu G, Slevin M and Badimon L: mCRP triggers angiogenesis by inducing F3 transcription and TF signalling in microvascular endothelial cells. Thromb Haemost 117: 357-370, 2017

57. Kopitz J, von Reitzenstein C, André S, Kaltner H, Uhl J, Ehemann V, Cantz M and Gabius HJ: Negative regulation of neuroblastoma cell growth by carbohydrate-dependent surface binding of galectin-1 and functional divergence from galectin-3. J Biol Chem 276: 35917-35923, 2001.

58. Manning JC, García Caballero G, Knospe C, Kaltner H and Gabius HJ: Network analysis of adhesion/growth-regulatory galectins and their binding sites in adult chicken retina and choroid. J Anat 231: 23-37, 2017.

59. García Caballero G, Schmidt S, Schnölzer M, SchlötzerSchrehardt U, Knospe C, Ludwig AK, Manning JC, Muschler P, Kaltner H, Kopitz J and Gabius HJ: Chicken GRIFIN: Binding partners, developmental course of localization and activation of its lens-specific gene expression by L-Maf/Pax6. Cell Tissue Res 375: 665-683, 2019.

60. García Caballero G, Schmidt S, Manning JC, Michalak M, Schlötzer-Schrehardt U, Ludwig AK, Kaltner H, Sinowatz F, Schnölzer M, Kopitz J and Gabius HJ: Chicken lens development: Complete signature of expression of galectins during embryogenesis and evidence for their complex formation with $\alpha-, \beta-, \delta$ - and $\tau$-crystallins, $\mathrm{N}-\mathrm{CAM}$, and $\mathrm{N}$-cadherin obtained by affinity chromatography. Cell Tissue Res 379: 13-35, 2020.

61. Gabius HJ: How to crack the sugar code. Folia Biol (Praha) 63: $121-131,2017$.

62. Kopitz J, Xiao Q, Ludwig AK, Romero A, Michalak M, Sherman SE, Zhou X, Dazen C, Vértesy S, Kaltner H, et al: Reaction of a programmable glycan presentation of glycodendrimersomes and cells with engineered human lectins to show the sugar functionality of the cell surface. Angew Chem Int Ed Engl 56: 14677-14681, 2017.

63. Ludwig AK, Michalak M, Xiao Q, Gilles U, Medrano FJ, Ma H, FitzGerald FG, Hasley WD, Melendez-Davila A, Liu M, et al: Design-functionality relationships for adhesion/growth-regulatory galectins. Proc Natl Acad Sci USA 116: 2837-2842, 2019.

64. Ludwig AK, Kaltner H, Kopitz J and Gabius HJ: Lectinology 4.0: Altering modular (ga)lectin display for functional analysis and biomedical applications. Biochim Biophys Acta Gen Subj 1863: 935-940, 2019.

65. Stone RC, Pastar I, Ojeh N, Chen V, Liu S, Garzon KI and Tomic-Canic M: Epithelial-mesenchymal transition in tissue repair and fibrosis. Cell Tissue Res 365: 495-506, 2016.

66. Haensel D and Dai X: Epithelial-to-mesenchymal transition in cutaneous wound healing: Where we are and where we are heading. Dev Dyn 247: 473-480, 2018.

67. Smetana K Jr, André S, Kaltner H, Kopitz J and Gabius HJ: Context-dependent multifunctionality of galectin-1: A challenge for defining the lectin as therapeutic target. Expert Opin Ther Targets 17: 379-392, 2013.

68. Romero A and Gabius HJ: Galectin-3: Is this member of a large family of multifunctional lectins (already) a therapeutic target? Expert Opin Ther Targets 23: 819-828, 2019. 